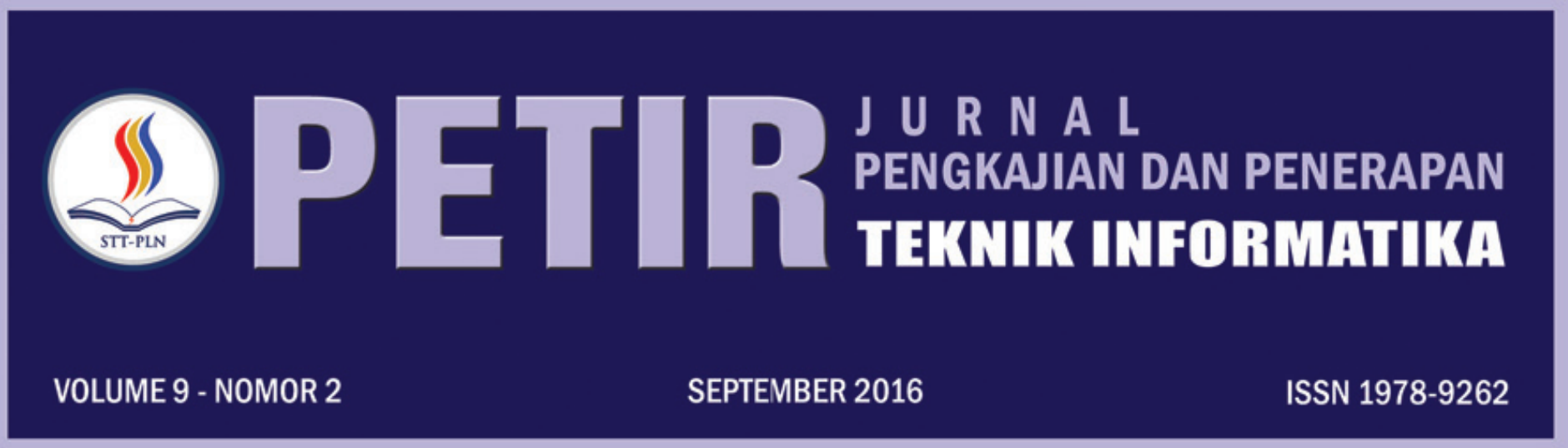

ANALISA SPASIAL UNTUK MELIHAT TINGKAT KESEJAHTERAAN MASYARAKAT DI PROVINSI BANTEN Muhamad Jafar Elly; Reza Pahlevi

PENENTUAN WILAYAH RAWAN PENYAKIT BERBASIS LINGKUNGAN DI JAKARTA TIMUR MENGGUNAKAN SISTEM INFORMASI GEOGRAFIS

Atiqah Meutia Hilda; Muhamad Jafar Elly; Windu Nugroho Cahyo Pamungkas

APLIKASI PENCARIAN USTADZ UNTUK WILAYAH DKI JAKARTA MENGGUNAKAN ALGORITMA HAVERSINE FORMULA BERBASIS ANDROID

Harni Kusniyati; Haries Fadhillah

PERENCANAAN ARSITEKTUR ENTERPRISE PERGURUAN TINGGI DENGAN PENDEKATAAN ENTERPRISE ARCHITECTURE PLANNING (EAP) (STUDI KASUS POLITEKNIK PIKSI GANESHA)

M. Farid Rifai

PERANCANGAN E-KATALOG PADA PERPUSTAKAAN DIGITAL STT-PLN BERBASIS WEB

Yessy Fitriani; Yasni Djamain; Risalatulina Dwi Kurniati

APLIKASI SISTEM GPS KEGIATAN OPERASIONAL PERSAMPAHAN DINAS PENGELOLAAN SAMPAH, PERTAMANAN DAN PEMAKAMAN (DP4) KOTA SUKABUMI

Yasmi Afrizal; Julian Chandra W
PERANCANGAN APLIKASI PENGOLAHAN DATA KAS BERBASIS ONLINE
(STUDI KASUS : KEMENTRIAN ' $X$ ')
Dian Hartanti; Lingga Desyanita

PERANCANGAN SISTEM INFORMASI PESERTA SERTIFIKASI

(Studi kasus LSP Piksi Ganesha)

Hendra Jatnika

RANCANG BANGUN APLIKASI SEC-WAY GUNA PENGINGAT BEPERGIAN DILENGKAPI INFO CUACA DAN CCTV JALAN RAYA LOKASI PILIHAN BERBASIS ANDROID STUDI KASUS DKI JAKARTA

Yasni Djamain; Intan Ratna Sari Yanti; Hari Wibowo

PREDIKSI PENERIMAAN SISWA BARU PADA MADRASAH ALIYAH AS-SAYAFI'IYAH 02 MENGGUNAKAN METODE TIME SERIES

Sarwo; Hermawan

PERANCANGAN SIMULASI MEDIA PEMBELAJARAN DENGAN METODE DIVISION REMAINDER UNTUK PENCARIAN ALAMAT RELATIF PADA PROSES PENEMPATAN DATA

Dewi Arianti Wulandari; Darma Rusjdi

ANALISIS SISTEM PENENTUAN LOKASI GANGGUAN JARINGAN DISTRIBUSI LISTRIK TERINTEGRASI GOOGLE MAP Abdul Haris; Herman Bedi Agtriadi

\begin{tabular}{|c|c|c|c|c|c|c|}
\hline \multirow{2}{*}{ 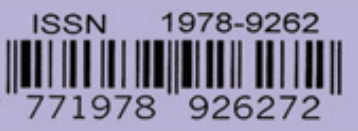 } & \multicolumn{6}{|c|}{ SEKOLAH TINGGI TEKNIK - PLN (STT-PLN) } \\
\hline & PETIR & VOL. 9 & NO. 2 & HAL. 89 - 166 & JAKARTA, SEPTEMBER 2016 & ISSN 1978-9262 \\
\hline
\end{tabular}




\title{
PENENTUAN WILAYAH RAWAN PENYAKIT BERBASIS LINGKUNGAN DI JAKARTA TIMUR MENGGUNAKAN SISTEM INFORMASI GEOGRAFIS
}

\author{
Atiqah Meutia Hilda1 ) Muhamad Jafar Elly²), Windu Nugroho Cahyo Pamungkas ${ }^{3)}$
}

\begin{abstract}
Abstrak
Jakarta Timur merupakan salah satu wilayah di DKI Jakarta yang rawan terhadap penyakit Deman Berdarah Dengue (DBD), Infeksi Saluran Pernafasan Akut (ISPA) dan Diare. Data statistik dari Suku Dinas Kesehatan Jakarta Timur menunjukan bahwa tingkat kerawanan terhadap penyakit DBD mencapai 100\%, ISPA 40\% dan Diare 10\%. Sayangnya, data angka tersebut kurang menggambarkan situasi yang sebenarnya secara spasial. Penelitian ini dilakukan untuk menentukan wilayah rawan penyakit berbasis lingkungan secara spasial di Jakarta Timur menggunakan Sistem Informasi Geografis (SIG). Kategori penyakit yang menjadi objek penelitian ini adalah penyakit DBD, ISPA dan Diare. Metode yang digunakan untuk menentukan kerawanan penyakit adalah metode skoring dan overlay. Berdasarkan hasil analisis dengan SIG, terdapat dua tingkat kerawanan penyakit yaitu "Rawan" dan "Sangat Rawan" dengan perincian sembilan dari sepuluh kecamatan di Jakarta Timur berada dalam status "Rawan" dan hanya satu wilayah dengan status "Sangat Rawan" yaitu Kecamatan Ciracas. Hasil analisis ini diharapkan dapat membantu pusat-pusat kesehatan masyarakat di Jakarta Timur dalam memantau penyebaran penyakit dan resikonya sehingga dapat mengantisipasi serta memberikan pelayanannya sedini dan seefektif mungkin.
\end{abstract}

Kata Kunci: Wilayah Rawan Penyakit, SIG, DBD, ISPA Diare

\section{Abstract}

East Jakarta is one of Jakarta areas that are prone to diseases Dengue Hemorrhagic Fever (DHF), Acute Respiratory Infections (ARI) and diarrhea. The Statistics data from Sub Department of Health, East Jakarta show that the level of vulnerability to dengue disease reached $100 \%, 40 \%$ of ARI and diarrhea $10 \%$. Unfortunately, the data figures were less describe the actual situation spatially. This research was conducted to determine areas vulnerable to desease based on spatial environment in East Jakarta using Geographic Information System (GIS). The category of desease which is the object of this research are the dengue disease, respiratory infection and diarrhea. The method used to determine disease susceptibility is scoring and overlay method. Based on the analysis with GIS, there are two levels of vulnerability to the disease namely "Vulnarable" and "Very Vulnerable" with details nine of the ten sub-districts in East Jakarta are in the status of "Vulnerable" and only one region with the status "Very Vulnerable" namely Ciracas District. The results of this analysis is expected to help the society health centers in East Jakarta in monitoring the spread of the disease and the risks so that they can anticipate and providing services as early and effectively as possible .

Keywords: Desease Vulnarable Area, GIS, DHF, ARI Diarrhea

\section{PENDAHULUAN}

Kesehatan merupakan salah satu faktor penting bagi kehidupan masyarakat. Pembangunan kesehatan diperlukan untuk meningkatkan kesadaran, kemauan dan kemam-puan hidup sehat bagi setiap orang agar terwujud derajat kesehatan masyarakat yang optimal. Faktor lingkungan dan peri-laku merupakan faktor terbesar yang ber-pengaruh terhadap tinggi rendahnya derajat kesehatan. Lingkungan merupakan determinan dalam menularkan dan munculnya suatu penyakit, baik menular maupun tidak menular. Salah satu wilayah yang masih memiliki masalah kesehatan masyarakat yang berkaitan dengan penyakit berbasis lingkungan adalah Jakarta Timur. Hal ini terlihat dari angka kesakitan dan kematian yang disebabkan faktor lingkungan masih cukup tinggi dan penyebarannya masih cukup luas di wilayah tersebut.
Beberapa penyakit berbasis lingkungan yang sampai sekarang menjadi masalah kesehatan antara lain Demam Berdarah Dengue (DBD), Infeksi Saluran Pernafasan Akut (ISPA) dan Diare. Salah satu upaya yang perlu dilakukan untuk memberantas penyakit ini adalah menggencarkan aspek pencegahan atau prefentif oleh Pusat Kesehatan Masyarakat (Puskesmas). Sayangnya, belum semua puskesmas melakukan upaya preventif secara maksimal karena sebagian besar puskesmas terfokus melakukan kegiatan kuratif saja. Selain itu, belum semua puskesmas melakukan analisa data kasus penyakit seperti membuat grafik maksimalminimal dan peta penyebaran wilayah rawan penyakit untuk mengetahui dan mengantisipasi lonjakan kasus penyakit tersebut. Saat ini analisa data penyebaran penyakit sebagian masih diolah secara manual dan semi otomatis. Sedangkan penyajian data dan informasi sebaran penyakit 
dalam bentuk peta yang dinamis juga belum dilakukan.

Dalam kurun waktu tiga tahun terakhir angka kesakitan akibat penyakit berbasis lingkungan di wilayah Jakarta Timur masih tergolong tinggi. Data jumlah penderita penyakit Demam Berdarah Dengue (DBD), Infeksi Saluran Pernafasan Akut (ISPA) dan Diare masih diolah dengan pendekatan statistik. Data statistik tersebut merupakan salah satu cara analisis dalam studi kesehatan. Gejala-gejalanya disajikan dan dipelajari dalam angka-angka. Kelemahannya, hasil analisis data statistik tersebut secara angka kurang dapat menggambarkan situasi yang sebenarnya tanpa memperhatikan dis-tribusi spasialnya. Bila hasilnya disajikan dengan menunjukkan distribusi keruangan atau lokasi termasuk sifat-sifat pentingnya, maka informasi tersebut ditunjukkan dalam bentuk peta (Bintarto \& Surastopo, 1991). Peta sebagai alat komunikasi antara pembuat peta dengan pengguna akan memudahkan dalam penyampaian informasi. Adanya Sistem Informasi Geografis (SIG) dapat memungkinkan pemantauan kesehatan masyarakat dan penyediaan informasi spasial tentang masalah kesehatan masyarakat khususnya penyakit yang berbasis lingkungan. Di samping itu, SIG dapat memberikan kemudahkan bagi puskesmas dalam menganalisa dan mengantisipasi terjadinya lonjakan penyakit tertentu di kawasan tersebut. Tujuan penelitian ini adalah untuk menyajikan kawasan-kawasan sebaran penyakit DBD, ISPA dan Diare dan memvisualisasikan pemetaan wilayah rawan penyakit berbasis lingkungan di Kota Administrasi Jakarta Timur. Hasil ini diharapkan dapat membantu Suku Dinas Kesehatan Jakarta Timur dalam memantau kesehatan masyarakat serta mengetahui penyebaran penyakit secara spasial sebagai bahan dalam pengambilan keputusan.

\section{METODE}

Metode penelitian meliputi identifikasi masalah, pengumpulan data melalui studi pustaka dan observasi, klasifikasi data dan analisis spasial. Data dianalisis secara spasial dengan menggunakan teknik tumpang susun atau overlay dan skoring. Analisis spasial tersebut dilakukan untuk menentukan tingkat kerawanan penyakit berbasis lingkungan. Perancangan basis data spasial adalah langkah selanjutnya untuk mengelola data spasial. Perancangan basis data spasial bertujuan untuk memberikan kemudahan pada pengguna dalam memperoleh informasi tentang tingkat kerawanan penyakit berbasis lingkungan di Jakarta Timur. Hasil analisis dan rancangan basis data spasial ini kemudian disajikan dalam bentuk web agar informasi tersebut dapat diakses secara luas oleh masyarakat.

Tahap kegiatan penelitian secara lengkap tampak dalam Gambar 1 berikut ini :

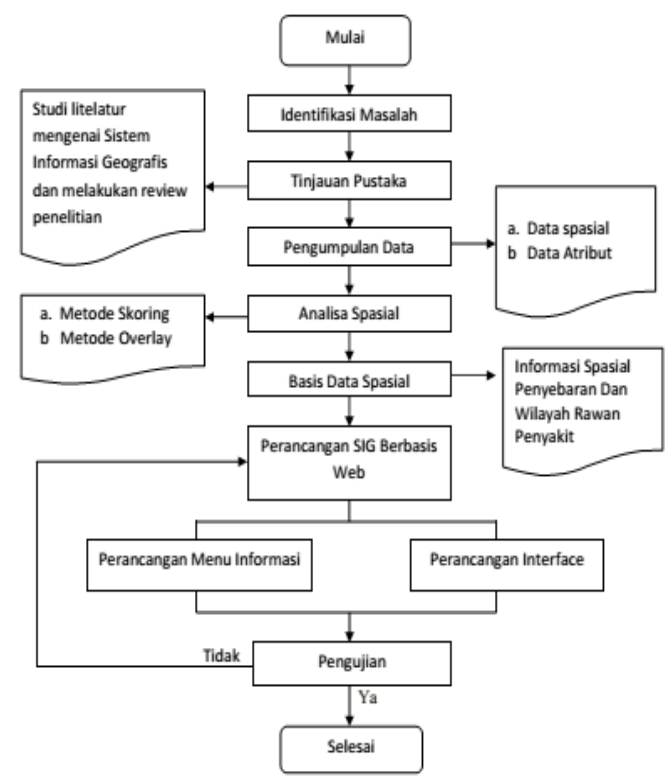

Gambar 1. Tahap-tahap penelitian penentuan tingkat kerawanan penyakit berbasis lingkungan di wilayah Jakarta Timur.

\section{HASIL DAN PEMBAHASAN}

\section{Proses Analisis Spasial}

Secara sederhana Johnston (2004) mengatakan bahwa analisis spasial mengarah pada banyak macam operasi dan konsep termasuk perhitungan sederhana, klasifikasi, penataan, tumpang susun geometris dan pemodelan kartografis. Ada berbagai cara yang dapat dilakukan dalam analisa untuk menyelesaikan masalah-masalah geografi yang melibatkan fenomena spasial. Dalam penelitian ini, analisis spasial dengan tek-nik tumpang susun atau overlay dan skoring digunakan untuk menentukan tingkat kerawanan penyakit berbasis lingkungan. Layer tematik yang digunakan terdiri atas peta Incident Rate (IR) tiap penyakit. Sedangkan metode skoring di-gunakan untuk menentukan tingkat kerawanan penyakit berbasis lingkungan. Sebelum dilakukan analisis spasial lebih lanjut, layer peta tematik harus melalui proses registrasi peta, digitasi dan klasifikasi data. Registrasi peta bertujuan untuk mengoreksi kesalahan geometrik yang masih dimiliki oleh data raster, sehingga data rester tersebut menjadi lebih akurat dan bisa diperoses lebih lanjut. Dalam kaitan ini, peta dasar yang digunakan adalah peta rupa bumi Kota Administasi Jakarta Timur dengan skala 1:25.000 yang diperoleh dari Badan Informasi Geospasial. Peta tersebut telah melalui proses registrasi dan digitasi yang mencakup 10 kecamatan, yakni Kecamatan Matraman, Kecamatan Pulogadung, Ke-camatan Jatinegara, Kecamatan Duren Sawit, Kecamatan Kramat Jati, Kecamatan Makasar, Kecamatan Pasar Rebo, Ke-camatan Cipayung, Kecamatan Ciracas dan Kecamatan Cakung. Peta wilayah Jakarta Timur hasil digitasi tampak dalam gambar 2 berikut ini. 


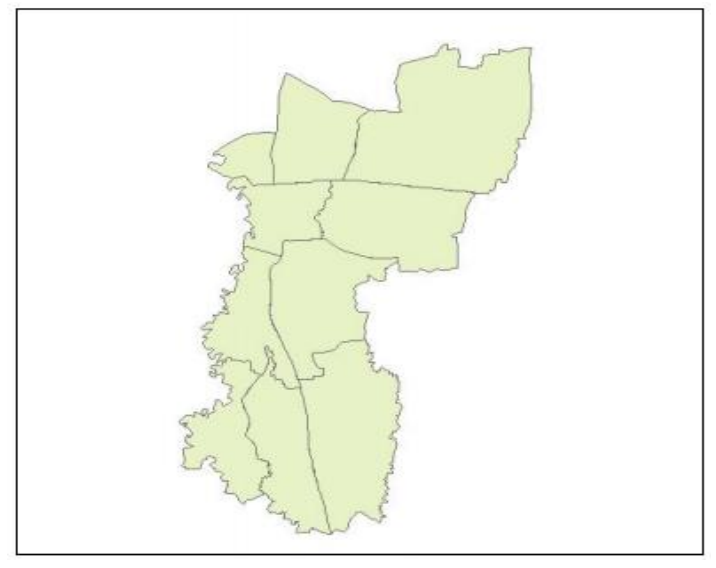

Gambar 2. Peta Wilayah Jakarta Timur hasil digitasi. (sumber : Badan Informasi Geospasial)

\section{Input Data Atribut dan Data Spasial}

Data geografis pada dasarnya tersusun oleh dua komponen penting yaitu data spasial dan data atribut. Data atribut dapat berupa informasi, statistik dan sebagainya. Data atribut yang dipakai untuk melengkapi data spasialnya berasal dari Suku Dinas Kesehatan Jakarta Timur dan Badan Pusat Statistik (BPS) Kota Administrasi Jakarta Timur. Data atribut tersebut meliputi data jumlah penduduk, kepadatan penduduk, jumlah kasus tiap penyakit, serta nilai Incident Rate (IR) tiap penyakit. Parameter yang digunakan untuk menentukan tingkat kerawanan penyakit adalah IR. Analisis spasial dimulai dari klasifikasi terhadap penentuan kriteria data yang dijadikan parameter penentu tingkat kerawanan penyakit. Klasifikasi data berkaitan dengan parameter data, jumlah kelas interval, batas kelas interval dan variabel visual. Data yang digunakan dalam analisis ini mengacu pada ketentuan kriteria yang dikeluarkan oleh Suku Dinas Kesehatan Jakarta Timur. Selanjutnya dilakukan proses klasifikasi data yang meliputi data jumlah penderita penyakit DBD, ISPA dan diare. Batas kelas interval berdasarkan nilai Incident Rate (IR) yang ditetapkan oleh Suku Dinas Kesehatan Jakarta Timur. Incident Rate merupakan parameter utama dalam penentuan tingkat kerawanan penyakit dan didukung dengan faktor lingkungan lain. Incident Rate (IR) merupakan perbandingan antara jumlah penduduk tertentu yang tertimpa peristiwa dalam kurun waktu tertentu dengan jumlah penduduk yang memiliki resiko mengalami peristiwa itu dalam kurun waktu yang sama.

IR berperan dalam penilaian derajat kesehatan masyarakat. Untuk mendapatkan nilai IR, data kejadian penyakit kemudian diolah dengan rumus sebagai berikut:

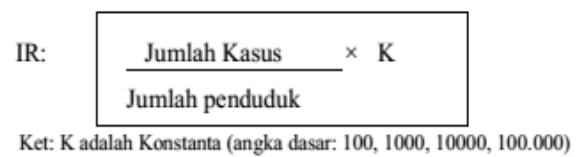

Masing-masing penyakit menggunakan angka konstanta yang berbeda. Untuk penyakit DBD dikalikan 100.000, penyakit ISPA dikalikan 10.000 dan Diare dikalikan 1000.

\section{Pemetaan Sebaran Penyakit Berbasis Ling- kungan}

Proses pemetaan klasifikasi data menghasilkan suatu pola keruangan yang dapat dikaji dan digunakan untuk menentukan tingkat kerawanan penyakit. Pola-pola tersebut diperjelas dengan penggunaan variabel visual warna untuk menggam-barkan nilai IR dalam pemetaan tingkat kerawanan penyakit berbasis lingkungan. Visual warna yang digunakan terdiri dari warna merah, kuning dan hijau. Berikut adalah peta sebaran penyakit DBD, Ispa dan Diare berdasarkan nilai IR penyakitnya.

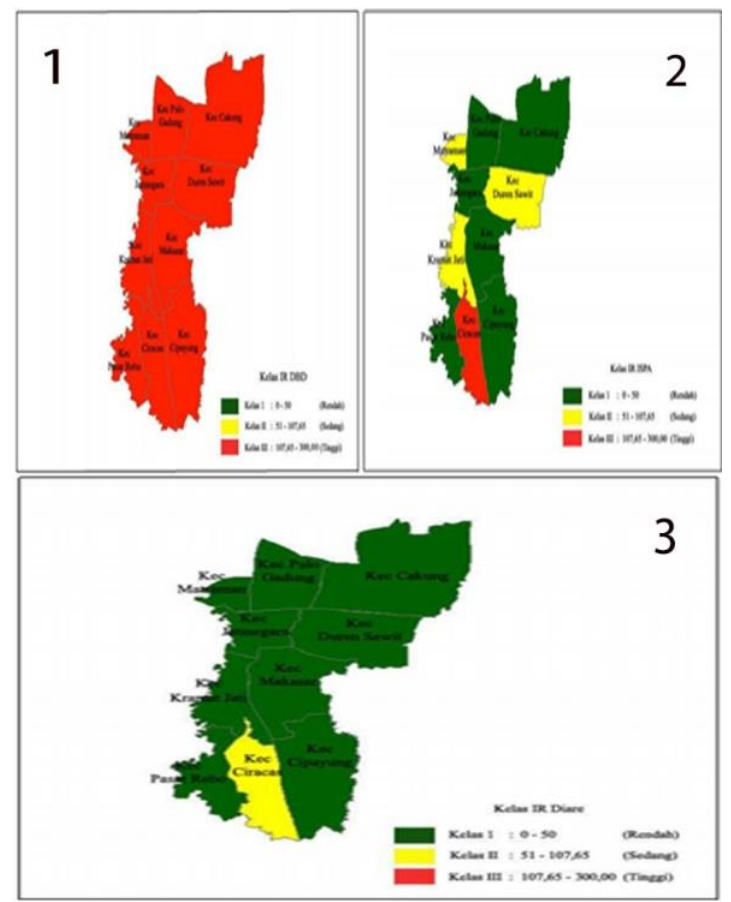

Gambar 3. Peta sebaran penyakit DBD (1), ISPA (2) dan diare (3) ber-dasarkan nilai IR

Hasil pemetaan data penyakit DBD tahun 2014 dapat dilihat pada gambar 3 (1) searah jarum jam. Ini adalah peta tingkat IR Penyakit DBD tahun 2014 di wilayah Jakarta Timur. Klasifikasi yang digambarkan dalam peta menunjukkan Incident Rate (IR) pada semua kacamatan berada di kelas III atau tinggi, Dengan rincian nilai IR Kecamatan Cakung $(126,4)$, Pulo Gadung $(186,7)$, Matraman (156,3), Duren Sawit $(266,9)$, Jatinegara $(176,5)$, Makasar (213,6), Kramat Jati (182), Cipayung $(200,4)$, Ciracas (168), dan Pasar Rebo $(193,4)$. Berdasarkan peta incident rate penyakit ISPA, tahun 2014 seperti tampak dalam gambar 3 (2), Kecamatan Ciracas adalah yang paling tinggi nilai IR nya yakni sebesar 114,2. Kecamatan yang termasuk dalam kelas II atau sedang adalah Kecamatan Kramat Jati $(63,6)$, Duren Sawit $(56,2)$ dan Matraman (66,1). Se-dangkan Kecamatan dengan kelas I atau rendah adalah Kecamatan 
Cakung (11,3), Pulo Gadung (35,4), Jatinegara $(35,6)$, Makasar $(19,6)$, Cipayung $(26,4)$ dan Pasar Rebo $(2,8)$. Sedangkan peta incident rate penyakt diare seperti tampak dalam gambar 3 (3) menunjukkan Kecamatan Ciracas berada di Kelas II atau sedang dengan nilai IR 57,7. Sedangkan untuk Kecamatan lain berada di kelas I atau terendah seperti Kecamatan Kramatjati dengan nilai IR $(28,3)$, Duren Sawit $(18,7)$, Matraman $(24,7)$ Cakung (13,3), Pulo Gadung $(22,7)$, Jatinegara $(35,8)$, Makasar $(30,7)$, Cipayung $(18,3)$ dan Pasar Rebo $(26,3)$.

Data yang digunakan dalam pemetaan data penyakit DBD, ISPA dan diare yaitu data jumlah kasus penyakit tahun 2014 per kecamatan. Data tersebut diperoleh dari Suku Dinas Kesehatan Jakarta Timur kemudian diolah dengan rumus untuk memperoleh nilai Incident Rate (IR) penyakit DBD sebagai dasar untuk peng-kelasan. Pengkelasan dan batas interval IR penyakit DBD berdasarkan kriteria yang ditetapkan oleh Suku Dinas Kesehatan Jakarta Timur. Jumlah kelas yang diguna-kan adalah tiga kelas.

Nilai skoring untuk ketiga jenis penyakit tersebut tampak dalam tabel berikut ini :

Tabel 1. Skoring penyakit DBD berdasarkan nilai IR

\begin{tabular}{|c|c|c|c|}
\hline No & Kecamatan & Skor & Status \\
\hline 1 & Cakung & 3 & Tinggi \\
\hline 2 & Pulo Gadung & 3 & Tinggi \\
\hline 3 & Matraman & 3 & Tinggi \\
\hline 4 & Duren Sawit & 3 & Tinggi \\
\hline 5 & Jatinegara & 3 & Tinggi \\
\hline 6 & Makasar & 3 & Tinggi \\
\hline 7 & Kramat Jati & 3 & Tinggi \\
\hline 8 & Cipayung & 3 & Tinggi \\
\hline 9 & Ciracas & 3 & Tinggi \\
\hline 10 & Pasar Rebo & 3 & Tinggi \\
\hline
\end{tabular}

Tabel 2. Skoring penyakit ISPA berdasarkan nilai IR

\begin{tabular}{|c|c|c|c|}
\hline No & Kecamatan & Skor & Status \\
\hline 1 & Cakung & 1 & Rendah \\
\hline 2 & Pulo Gadung & 1 & Rendah \\
\hline 3 & Matraman & 2 & Sedang \\
\hline 4 & Duren Sawit & 2 & Sedang \\
\hline 5 & Jatinegara & 1 & Rendah \\
\hline 6 & Makasar & 1 & Rendah i \\
\hline 7 & Kramat Jati & 2 & Sedang \\
\hline 8 & Cipayung & 1 & Rendah \\
\hline 9 & Ciracas & 3 & Tinggi \\
\hline 10 & Pasar Rebo & 1 & Rendah \\
\hline
\end{tabular}

Tabel 3. Skoring Penyakit Diare berdasarkan nilai IR

\begin{tabular}{|c|c|c|c|}
\hline No & Kecamatan & Skor & Status \\
\hline 1 & Cakung & 1 & Rendah \\
\hline 2 & Pulo Gadung & 1 & Rendah \\
\hline 3 & Matraman & 1 & Rendah \\
\hline 4 & Duren Sawit & 1 & Rendah \\
\hline 5 & Jatinegara & 1 & Rendah \\
\hline 6 & Makasar & 1 & Rendah \\
\hline 7 & Kramat Jati & 1 & Rendah \\
\hline 8 & Cipayung & 1 & Rendah \\
\hline 9 & Ciracas & 2 & Sedang \\
\hline 10 & Pasar Rebo & 1 & Rendah \\
\hline
\end{tabular}

Analisis data dengan teknik overlay terhadap parameter IR

$$
\mathrm{Ki}=\frac{\mathrm{Xt}-\mathrm{Xr}}{\mathrm{k}}
$$

Keterangan:

$\mathrm{Ki}=$ Interval Kelas

$\mathrm{Xt}=$ Data tertinggi

$\mathrm{Xr}=$ Data terendah

$\mathrm{k}=$ Jumlah kelas yang diinginkan

tiap penyakit yang sudah diberi nilai diproses dengan metode scoring. Proses skoring sendiri merupakan pengharkatan pada setiap satuan unit pemetaan kemudian ditumpangsusunkan. Pemberian skor pada parameter berbeda-beda, yaitu dengan memperhatikan seberapa besar pengaruh parameter-parameter tersebut terhadap tingkat kerawanan penyakit. Semakin besar pengaruh parameter tersebut terhadap tingkat kerawanan penyakit maka nilai bobotnya juga besar, sebaliknya jika pengaruhnya kecil maka nilai bobotnya juga kecil. Pengharkatan ini digunakan untuk menentukan tingkat kerawanan suatu wilayah terhadap penyakit berbasis lingkungan berdasarkan nilai IR pada tiga penyakit yaitu DBD, ISPA dan Diare. Peta tingkat kerawanan penyakit berbasis lingkungan diperoleh dengan menumpangsusunkan informasi tingkat sebaran penyakit DBD, ISPA dan Diare. Berikut merupakan hasil skoring untuk peta sebaran penyakit DBD, ISPA dan Diare :

Tabel 4. Skoring Incident Rate (IR) Penyakit DBS, ISPA dan diare

\begin{tabular}{|c|c|c|}
\hline Kelas & IR & Skor \\
\hline Kelas I $: 0.00-50.00$ & Rendah & 1 \\
\hline Kelas II $: 50.01 \cdot 107.65$ & Sedang & 2 \\
\hline Kelas III $: 107.66-500.00$ & Tinggi & 3 \\
\hline
\end{tabular}

Keterangan: nilai K untuk penyakit DBD 100.000 , ISPA 10.000 dan Diare 1000 
Setelah parameter diberikan skor, proses overlay dilakukan untuk menghasilkan peta sebaran ketiga jenis penyakit tersebut. Selanjutnya skor ketiga parameter tersebut ditotal lagi kemudian diklasifikasi menjadi tiga kelas. Penentuan tingkat kerawanan penyakit berdasarkan skor total dari hasil penjumlahan parameter IR penyakit. Dalam penentuan ini, nilai interval kelas tingkat kerawanan penyakit diperlukan untuk membedakan status kerawanan penyakit antara yang satu dengan yang lain. Formula yang digunakan untuk membuat kelas interval adalah formula Sturgess sebagai berikut:

Nilai interval ditentukan dengan pendekatan relatif dengan cara melihat nilai maksimum dan nilai minimum tiap satuan pemetaan. Kelas interval didapatkan dengan cara mencari selisih antara data tertinggi dengan data terendah dan dibagi dengan jumlah kelas yang diinginkan. Tingkat kerawanan penyakit da-lam penelitian ini dibagi menjadi tiga kategori seperti tampak dalam tabel 5 berikut ini :

Tabel 5. Skor Akhir Tingkat Kerawanan Pe-nyakit DBD, ISPA dan Diare

\begin{tabular}{|c|c|}
\hline Jumlah Skor Parameter & Tingkat Kerawanan \\
\hline $1-3$ & Tidak Rawan \\
\hline $4-6$ & Rawan \\
\hline $7-9$ & Sangat Rawan \\
\hline
\end{tabular}

Analisis data spasial dengan metode overlay dan skoring ini menghasilkan peta tingkat kerawanan penyakit yang merupakan gabungan tiga peta sebelumnya, yaitu peta sebaran IR penyakit DBD, ISPA dan Diare. Peta tersebut digunakan untuk mendapatkan hasil analisis akhir tingkat kerawanan penyakit. Berikut merupakan peta hasil overlay dan skoring ketiga peta sebaran IR penyakit DBD, ISPA dan Diare:

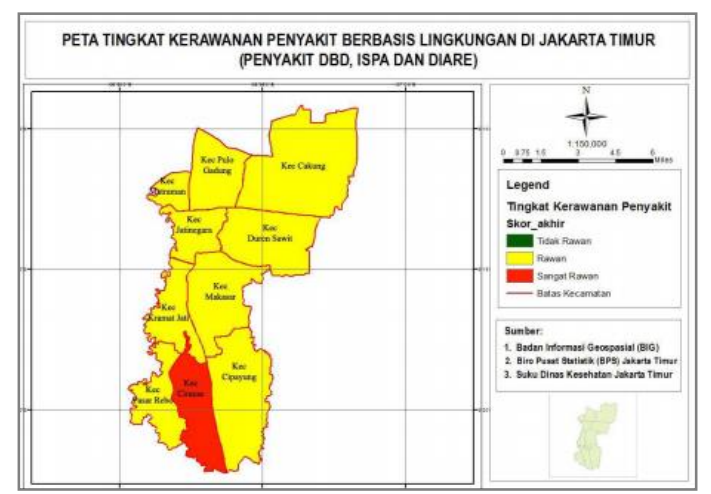

Gambar 4. Peta sebaran Tingkat Kerawanan Penyakit DBD, ISPA dan diare di wilayah Jakarta Timur

Hasil analisis sebagaimana ditunjukkan dalam peta sebaran tingkat kerawanan penyakit di atas, terdapat Sembilan dari sepuluh Kecamatan di Jakarta Timur berada di kelas 2 atau dikategorikan wilayah rawan penyakit DBD, ISPA dan diare, yaitu Kecamatan Cakung, Kecamatan Pulo Gadung, Kecamatan Matraman, Kecamatan Duren Sawit, Kecamatan Jatinegara, Kecamatan Makasar, Kecamatan Kramat Jati, Kecamatan Cipayung dan Kecamatan Pasa Rebo. Sedangkan satu wilayah berada i kelas III atau dikategorikan wilayah sangat rawan penyakit DBD, ISPA dan diare yaitu Kecamatan Ciracas.

Berikut merupakan total skor akhir dari nilai penjumlahan skor penyakit DBD, ISPA dan Diare

Tabel 6. Total Skor Tingkat Kerawanan Penyakit DBD, ISPA dan Diare

\begin{tabular}{|c|c|c|c|c|c|c|}
\hline \multirow[t]{2}{*}{ No } & \multirow[t]{2}{*}{ Kecamatan } & \multicolumn{3}{|c|}{ Skor } & \multirow{2}{*}{$\begin{array}{l}\text { Total } \\
\text { Skor }\end{array}$} & \multirow{2}{*}{$\begin{array}{c}\text { Tingkat } \\
\text { Kerawanan }\end{array}$} \\
\hline & & DBD & ISPA & Diare & & \\
\hline 1 & Cakung & 3 & 1 & 1 & 5 & Rawan \\
\hline 2 & Pulo Gadung & 3 & 1 & 1 & 5 & Rawan \\
\hline 3 & Matraman & 3 & 2 & 1 & 6 & Rawan \\
\hline 4 & Duren Sawit & 3 & 2 & 1 & 6 & Rawan \\
\hline 5 & Jatinegara & 3 & 1 & 1 & 5 & Rawan \\
\hline 6 & Makasar & 3 & 1 & 1 & 5 & Rawan \\
\hline 7 & Kramat Jati & 3 & 2 & 1 & 6 & Rawan \\
\hline 8 & Cipayung & 3 & 1 & 1 & 5 & Rawan \\
\hline 9 & Ciracas & 3 & 3 & 2 & 8 & Sangat Rawan \\
\hline 10 & Pasar Rebo & 3 & 1 & 1 & 5 & Rawan \\
\hline
\end{tabular}

Tabel 6 menunjukkan bahwa semua wilayah di Jakarta Timur mendapatkan nilai skor 3 atau tergolong tinggi untuk penyakit DBD. Parameter yang diduga menjadi penyebab timbulnya penyakit DBD adalah kepadatan penduduk dan parameter lingkungan fisik yang terkait berkembangnya faktor penyakit yaitu kualitas air sungai dan parameter perilaku masyarakat yaitu volume sampah. Untuk penyakit ISPA ada satu wilayah yang mendapatkan skor 3 atau tergolong tinggi yaitu Kecamatan Ciracas dan tiga wilayah yang mendapatkan skor 2 atau tergolong sedang yaitu Kecamatan Matraman, Duren Sawit dan Kramat Jati. Parameter yang diduga menjadi penyebab timbulnya penyakit ISPA adalah kepadatan penduduk, dan parameter lingkungan fisik yaitu kualitas udara dan parameter perilaku masyarakat yaitu volume sampah. Sedangkan untuk penyakit Diare, hanya satu wilayah tergolong sedang dengan skor 2 yaitu Kecamatan Ciracas, 9 wilayah lainnya tergolong tidak rawan dengan skor 1. Parameter yang diduga menjadi penyebab timbulnya penyakit Diare adalah parameter lingkungan fisik yaitu kualitas air sungai dan parameter perilaku masyarakat yaitu volume sampah. Secara keseluruhan wilayah Kecamatan Ciracas adalah wilayah yang tergolong sangat rawan penyakit berbasis lingkungan di Jakarta Timur setelah dilakukan analisa dengan metode skoring dan overlay menggunakan Sistem Informasi Geografis (SIG). Parameter yang diduga menjadi penyebab 
kerawanan tersebut sangat variatif antara lain kepadatan penduduk, lingkungan fisik meliputi kualitas air sungai dan udara dan perilaku masyarakat yaitu volume sampah yang berlebihan.

\section{Basis Data Spasial}

Rancangan basisdata spasial ini berbeda dengan perancangan basisdata biasa. Basisdata spasial dirancang sedemikian rupa sebagai wadah untuk mengelola, memperbarui, memasukkan dan menganalisis data spasial yang bereferensi geografis. Basisdata spasial mencakup juga data atribut yang menjelaskan tentang objek dianalisis. Rancangan basisdata spasial sebagaimana di tunjukkan dalam gambar 9, menjelaskan tentang proses pembuatan basisdata spasial hingga data bisa diolah dan akhirnya menghasilkan informasi spasial tentang tingkat kerawanan penyakit DBD, ISPA dan diare di wilayah Jakarta Timur.

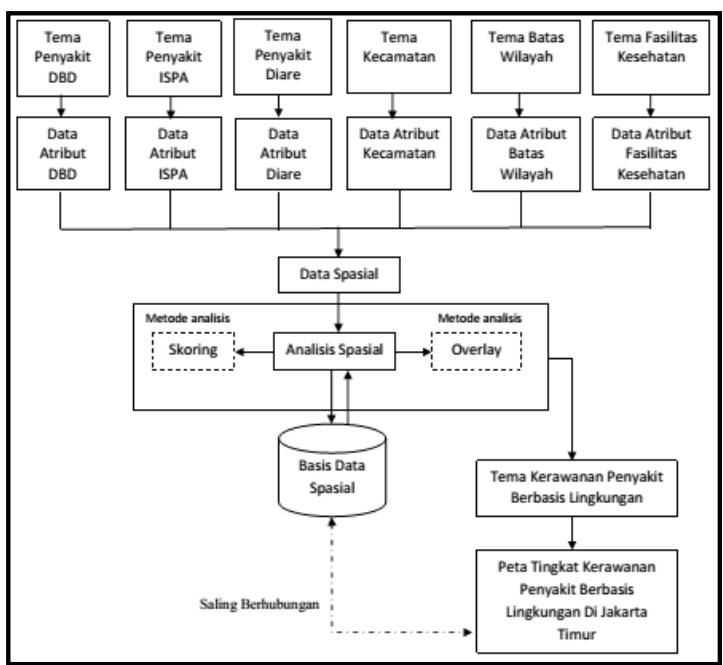

Gambar 9. Rancangan Basis Data Spasial untuk menentukan tingkat kerawanan penyakit DBD, ISPA dan diare di wilayah Jakarta Timur.

Hasil informasi spasial ini kemudian bisa diakses melalui web. Teknologi yang digunakan untuk mengakses peta tingkat kerawanan penyakit ini dikenal dengan istilah WebGIS atau Sistem Informasi Geografi berbasis web. Rancangan Web-GIS dan hasilnya tampak dalam gambar 10 berikut ini.

\section{SIMPULAN}

Berdasarkan hasil analisis tersebut, sembilan dari sepuluh kecamatan di Jakarta Timur berada dalam status "Rawan" dan hanya satu wilayah dengan status "Sangat Rawan" yaitu Kecamatan Ciracas. Faktor yang diduga menjadi penyebab sangat rawannya wilayah

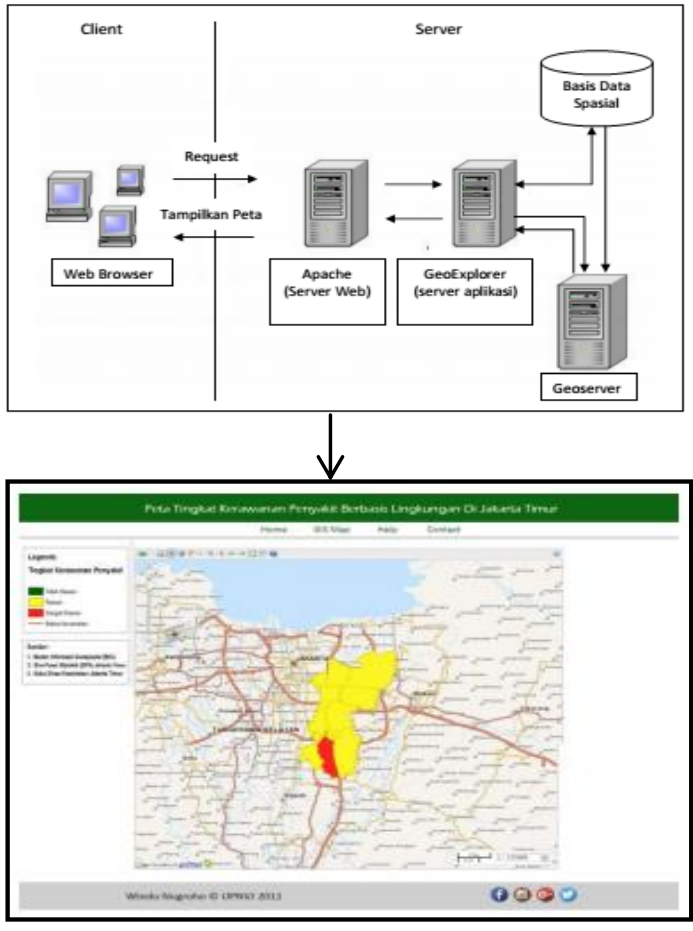

Gambar 10. Rancangan WebGIS dan tampilan peta tingkat kerawanan penyakit DBD, ISPA dan diare di wilayah Jakarta Timur.

Ciracas terhadap penyakit berbasis lingkungan antara lain karena masih berpotensinya banjir dan meluapnya air sungai yang melintasi wilayah Ciracas saat musim hujan yang mengakibatkan volume sampah berlebihan. Selain itu mobilitas penduduk dan kegiataan transportasi yang tinggi juga terjadi di wilayah Ciracas sehingga mengakibatkan pencemaran udara yang lebih tinggi dibandingkan wilayah la innya.

\section{SARAN}

Simpulan di atas belum memasukkan faktor penentu kerawanan penyakit dan nilai keterhubungannya dengan parameter penentu yang lain. Oleh karena itu, hasil ini masih perlu diteliti lebih lanjut untuk mendapatkan hasil yang lebih akurat. Namun demikian, hasil simpulan tersebut dapat dijadikan rujukan kepada pihakpihak yang berkepentingan untuk membuat kebijakan di bidang kesehatan maupun pendidikan kesehatan

\section{DAFTAR PUSTAKA}

Aronoff, S 1993, Geographic Information System: A Management Perspective, Third Printing, ISBN 0-921804-91-1, P:294, Canada.

Bintarto dan Surastopo, 1991, Metode Analisis Geografi, LP3ES, Jakarta.

Biro Pusat Statistik (BPS) 2014, Jakarta Timur Dalam Angka. Publikasi BPS Kota-madya Jakarta Timur 
Budiyanto, Eko 2010, Sistem Informasi Geografis dengan Arc5ew GIS, Andi, Yogyakarta.

Departemen Kesehatan RI 2004, Sistem Kesehatan Nasional, Jakarta

Elliott, P. et al, 2000, Spatial Epidemiology : Method and Applications, University Press, Oxford.

Elly, M.J 2008, SISTEM INFORMASI GEOGRAFIS Menggunakan Aplikasi Arc5ew 3.2 dan ERMapper 6.4, Edisi Pertama, Graha IImu, ISBN: 978 -979-756-497-1, Yogyakarta.

Indriasih, E 2008, 'Sistem Informasi Geo-grafis Dalam Bidang Kesehatan Masyarakat' vol 11, no 1 Januari 2008 hlm 99 - 104.

Iqbal, W. M dan Nurul Chayatin 2010, Kesehatan Masyarakat Teori dan Aplikasi, Graha Media, Bandung

Notoatmodjo, 2010, Kesehatan Masyarakat IImu dan Seni, Jakarta
Painho, M, 2001, WebGIS as a Teaching Tool, California.

Prahasta, Eddy 2002, Konsep-konsep dasar SIG, Penerbit Informatika, Bandung.

Prahasta, Eddy 2007, Membangun Aplikasi Web-based GIS dengan MAPSERVER, Penerbit Informatika, Bandung.

Prahasta, Eddy 2009, Sistem Informasi Geo-grafis, Penerbit Informatika, Bandung.

Suku Dinas Kesehatan Jakarta Timur 2014, Laporan Tahunan Penyakit DBD, ISPA dan Diare. Tersedia dari Publikasi Kesehatan Masyarakat. 